\title{
МЕДІАЛІНГВІСТИКА
}

Visn. Lviv. Univ., Ser. Zhurn. 2019: 45; 299-307 • DOI: http://dx.doi.org/10.30970/vjo.2019.45.10012

УДК 81 ' $42=161.2$

\section{СПЕЦИФІКА ЛІНГВАЛІЗАЦІЇ КОНЦЕПТУ «МИР» У МАС-МЕДІЙНОМУ ТЕКСТІ}

\section{Тетяна Вільчинська}

Тернопільський національний педагогічний університет імені Володимира Гнатюка, вул. М. Кривоноса, 2, 46027, Тернопіль, Украӥна

e-mail: tetyanav@ukr.net

https://orcid.org/0000-0003-4881-6132

Статтю присвячено лінгвокогнітивному аналізу концепту «мир», реалізованому на шпальтах тернопільського регіонального видання - газети «Свобода». Розглянуто основні засоби мовної об’єктивації дослідженого концептуалізованого поняття, з'ясовано його семантико-аксіологічну природу.

Ключові слова: концепт, мир, вербалізатор, мас-медійний текст, газета «Свобода».

У еволюційному поступі людства порубіжжя XX-XXI ст., за словами О. Сербенської, характеризується розумінням могутності творчої духовної потенції, усвідомленням великої рушійної сили людського духу, буттям якого є мова. Саме цим дослідниця пояснює активізацію наукового інтересу до науки про мову, зауважуючи, що «кількість самостійних мовознавчих дисциплін (а самостійною дисципліна стає тоді, коли чітко виділяється об'єкт наукового пізнання і методи його дослідження) постійно зростає, тому мову можна вивчати 3 найрізноманітніших поглядів і в найрізноманітніших аспектах» [1, с. 25-26].

Саме такий інтердисциплінарний підхід реалізований у запропонованій розвідці, виконаній у лінгвокогнітивному, лінгвокультурному аспекті та присвяченій дослідженню особливостей лінгвалізації концепту «мир» у мас-медійному тексті.

Отже, об’єктом аналізу став важливий для української етноспільноти, передусім у контексті російської агресії і військових дій в Україні 2014-2019 рр., концепт «мир» як репрезентант універсальної бінарної опозиції «війна-мир»; предметом особливості його номінації, семантико-когнітивна природа, аксіологічно-образні характеристики; матеріалом - мас-медійний текст, зокрема газетний, насамперед 3 огляду на його прагматичний потенціал.

Зазначимо, що вивчення особливостей мовної концептуалізації культурного простору через концепти уже протягом тривалого часу належить до пріоритетних напрямків у сучасній лінгвістиці. Відтак чимало концептуальних одиниць уже були

(C) Вільчинська Т., 2019 
об’єктом грунтовних лінвокогнітивних студій. Водночас, передусім з огляду на соціально-політичну та ідеологічну ситуацію в країні, сьогодні актуалізується багато концептуально значущих понять, що потребують докладного аналізу. До таких, зокрема, належить і оцінно маркований, когнітивно багатоплановий, полісемантичний концепт «мир».

Зауважимо, що «Словник української мови» в 11 томах фіксує дві різні за значенням лексеми мир: першу - на позначення згоди, спокою, тиші, протилежне війні і другу - для називання землі з усім, що на ній існує, тобто світу, людей і под. [2, с. 712].

Окреслений у дослідженні концепт пов'язуємо насамперед із поняттям миру як антипода війни, як компонента відповідної бінарної опозиції, властивої концептам категорійного світу, протиставлюваним на основі позитивного і негативного. Окремі фрагменти аналізу концептуалізованих понять війни (боротьби, протистояння) і миру (спокою, злагоди) демонструють праці Л. Венедиктової, Т. Вільчинської, У. Карпенко-Іванової, О. Колесник, П. Нікітіної, Г. Яворської, проте актуальним залишається їхнє студіювання в мас-медійних текстах.

Газетний текст є одним із найдавніших видів медіатексту, тому неодноразово перебував у колі дослідницьких зацікавлень (Т. Добросклонська, Х. Дацишин, М. Луканіна, Н. Нестерова, О. Сербенська, Л. Ставицька, Н. Стеценко. Г. Черненко та ін.). Проте сьогодні активізується передусім інтерес до нього як засобу впливу і переконання. Від газетного тексту, як загалом й інших видів медіатекстів, очікують використання загальнозрозумілих сценаріїв та загальнодоступних засобів їхнього вираження [3, с. 128].

Матеріалом дослідження послужили публікації про воєнні дії в Україні, представлені в регіональному виданні Тернопільської області - газеті «Свобода», яке справедливо можна назвати рупором суспільної думки на Тернопільщині. 3'явившись із початком війни, подібні матеріали не зникають із газетних шпальт та відіграють важливу роль у формуванні настроїв і переконань краян. Щодо їхнього студіювання, то дослідження об’єктивації концепту «мир» на сторінках газети «Свобода» проводиться вперше.

Про зв'язок концепту з вербальними засобами йдеться практично у всіх його визначеннях. Здебільшого перевагу надають слову (В. Жайворонок), слову і словосполученню, що йому дорівнює (Ю. Степанов), а також фразеологічним одиницям, реченням, цілим текстам (Н. Мех) тощо. За 3. Поповою і Й. Стерніним, «сукупність мовних засобів, що об'єктивують концепт у конкретний період розвитку суспільства, становить його номінативне поле» [П4, с. 66], яке моделюється шляхом суцільної вибірки прямих номінацій концепту, їхніх синонімів, дериватів, оказіональних індивідуально-авторських назв, фразеологічних одиниць у широкому розумінні тощо.

Основним мовним репрезентантом досліджуваного концепту є позитивно маркована лексема мир, напр.: Мир - ие наше головне прагнення [5, 2014, №50, с. 2].

Слово мир загальнослов'янське: болг., серб. й рос. мир, чеське й польське mir. Корінь цього слова - праіндоєвропейський; старолитовське mieras - «мир», «сnокій»; латинське - miers (те саме значення); албанське тіre - «гарний», «добрий», «дружелюбний». У Лексисі 1596 р.: «Мир - покой». У Лексиконі 1627 р.: «Мирныйспокойный» [2, с. 42], відповідно в досліджуваних текстах: Дякую Вам за те, щяо ви забезпечуєте мир і спокій на території Тернопільської області та виконуєте бойові завдання на сході України [5, 2018, №50, с. 2]. 
I. Огієнко зазначає такі українські похідні слова від іменника мир: мирити, миритися, помиритися, замиритися, мирний, мирно, сумирний, мировий, примирливий та зложені з компонентом мир (спокій): миролюбець, миролюбивий, миротворець $[2$, c. 43]. Аналізований матеріал засвідчує, що подібні словотвірні деривати, похідні від основного імені концепту, є не менш продуктивними в аспекті вербалізації концепту «мир».

Переважає з-поміж них насамперед назва мирний, яка, вживаючись частіше в складі двокомпонентних атрибутивних синтагм, об'єктивує різні концептуальні ознаки, пов'язані з миром, що став найзаповітнішою мрією українців, напр.: мирний план (Водночас до режиму припинення вогню можна повернутися в будь-який момент, коли всі сторони дотримуватимуться основних пунктів мирного плану [5, 2014, №52, с. 4]); мирний час (Такі об'єднання чимось схожі із козацькими полками минулого, котрі у мирний час працювали, а при потребі організовували оборону [5, 2014, №46, с. 3]); мирні громадяни, мешканиі, люди (Захист територіальної иілісності Украӥни, безпеки й життя мирних громадян потребує не лише оборонних, але й наступальних дій проти терористів [5, 2014, №55, с. 4]; Найбільше тішить, щяо активнішими стали так звані мирні мешканці $[5,2014$, №46, с. 2]; Чим завинили мирні люди? [5, 2017, №50, с. 6]); мирна держава, країна, Україна (За себе йому не страшно, але хотів би залишити після себе дітей, і щьоб вони обов'язково жили у мирній державі [5, 2014, №55, с. 4]; В ті страшні дні Іловайського котла, жінка, яка була прикутою до стовпа і готовою до смерті, давала надію всій мирній краӥні $[5,2018$, №17, с. 6]; Діти відтворили на папері Украӥну майбутнього такою, якою вони хотіли б бачити ї̈ наяву -ммрною... [5, 2017, №26, с. 3]); мирне небо з мирними літаками і мирні квартали (Під кулями вояки Національної гвардї, спецппизначенці, усі, кому не байдужа подальша доля нашої держави, забезпечують мирне небо - зміст изих двох простих слів сьогодні, як ніколи, розуміє, напевне, кожен [5, 2014, №48, с. 2]; Вочевидь, теперішній світ дійшов до ручки, якщз бандюки у ньому можуть привласнити собі навіть небо, розстрілявщи мирний літак...[5, 2014, №59, с. 11]; Можливо, $\epsilon$ якісь здогади, чому обстрілюють мирні квартали, а не військових? [5, 2017, №50, с. 6]); мирна пропозиція (Вочевидь, такою була їхня відповідь на мирну пропозицію офіиійного Києва [5, 2014, №48, с. 2]); мирна ініціатива (Тому Росія до кіния буде відмовлятися від будь-яких мирних ініціатив, адже Путін зацікавлений у продовженні військового конфлікту [5, 2014, №50, с. 3]); мирний шлях (Крім того, влада готова утримати ситуацію і має можливості для наведення ладу на сході України мирним шляхом... [5, 2014, №29, с. 4]); мирне життя (Та ніяк не міг знайти собі місие у мирному жнитті [5, 2017, №22, с. 6]) та ін.

Про деякі з подібних синтагм сьогодні можна говорити як про усталені, як-от мирний план Порошенка: За два наступні дні після інавгуращії контактна група $з$ представників України, Росії та ОБСЕ провела три засідання і досягла згоди шзодо ключових положень мирного плану Порошенка $[5,2014$, №46, с. 2] або Адже очевидно, щуо Путін діє за власним планом збройної агресії, «мирний план Порошенка" він відкинув і виконувати не збирається [5, 2014, №59, с. 2].

Нерідко автори газетних публікацій послуговуються атрибутивними синтагмами 3 прикметником миротворчий, в тому числі й у переносному значенні. Пор.: Переконаний, призивати потрібно не всіх підряд, а насамперед тих, хто має бойовий чи миротворчий досвід та /або під час служби пройшов повночінну бойову 
підготовку... [5, 2014, №59, с. 2]; Критичної ситуації для повернення миротворчого контингенту зараз немає... [5, 2015, №48, с. 2] та Росія дійсно зосередила на кордоні з Україною велике угрупування військ і військової техніки з маркуванням «миротвориі сили» [5, 2014, №57, с. 3]; Якщо утвердити той факт, що Росія є державою-агресором, російські війська вважатимуть окупантами, навіть якщо вони з п'ят до вух будуть розфарбовані у «миротворчі кольори» [5, 2014, №57, с. 3] .

Виявлено і приклади вживання трикомпонентних атрибутивних синтагм на зразок миролюбива украӥнська земля: Нинішнього року молитва буде особливою, бо вороги зазіхають на миролюбиву украӥнську землю, ї̈ ияілісність та європейський вибір [5, 2014, №50, с. 1].

Серед вербалізаторів концепту «мир» чимало також іменникових деривативних утворень. Одні з них вживаються на позначення учасників бойових дій, як-от назва миротвориі: Які ще аргументи, скільки смертей патріотів потрібно, щоб відкликати нарешті миротворців з Конго і Ліберії?! [5, 2014, №44, с. 2] чи супермиротвориі: Між іншим, російське керівництво, яке зараз «корчить» із себе супермиротворців, у Чечні не дуже черемонилося з мирними жителями та відновлювало територіальну цілісність Росії, незважаючи на численні жертви [5, 2014, №50, с. 1] (префікс супер- тут засвідчує не силу і мужність бійців, а конотує іронічне ставлення до них), що, зазнавши переосмислення, виступає також у новому значенні: Забігаючи наперед, скажу, що сайт «Миротворець»... намагався розслідувати июю справу [5, 2018, №17, с. 6]; інші - для називання мирних процесів, станів на кшталт перемир'я, умиротворення, примирення: Час перемир'я треба повноцінно використовувати для підготовки власної оборони [5, 2015, №33, с. 3]; Шеварднадзе тоді тричі підписував перемир'я, $і$ щоразу Путін використовував його, аби перегрупувати війська $і$ захопити нові території [5, 2014, №50, с. 3]; Стан умиротворення дуже важливий для кожного, бо дає змогу бути потрібним комусь, втілити мрії, залишити достойний житейський слід [5, 2014, №74, с. 1]; - Тому наме завдання - зробити все для того, щоб иі люди були символом єдності, примирення та символом майбутнього, - підкреслив Степан Барна [5, 2017, №37, с. 1].

Щодо останніх, то вони засвідчують загальномовну практику номінування відсутності збройної боротьби, котра в лексикографічних джерелах знаходить підтвердження в таких синонімах до слова мир, як спокій, покій, заст. замирення, примирення, примир'я, розм. розмир та перемир'я [7, с. 826].

Динамічну ознаку реалізують похідні, виражені дієсловами, напр.: Звісно, Петро Олексійович не захотів із иим миритися... [5, 2014, №44, с. 1].

Виявлено також чимало контекстів, у яких вербалізаторами концепту «мир» виступають синонімічні вирази, виражені номінативними та предикативними двокомпонентними синтагмами, як-от припинення вогню, скласти зброю, здавати багнети, досягти компромісу, ховати патрони та под.: Головна мета -знову домогтися одностороннього припинення вогню $[5,2014$, №55, с. 3]; Україна втратила стількох своїх найкращих дітей, що вже найвища пора скласти зброю $[5,2015$, №46, с. 2]; рідше - багатокомпонентними: Триває оголошений Президентом так званий мирний план припинення війни на сході, про його результати буде відомо за кілька днів [5, 2014, №50, c. 2].

Нерідко подібні синтагми будуються на основі слів іншомовного походження, напр.: 18 квітня вона вилетіла на східну Украӥну для того, щоб особисто перевірити 
ситуацію і вжити посилених заходів для мирного вирішення конфлікту [5, 2014, №34. с. 3] або Сьогодні політики, особливо вищяого ешелону, намагаються досягти компромісу зі сходом [5, 2014, №34, с. 2].

Нерідко поняття миру заперечується, що по суті означає війну та свідчить про тісний взаємозв'язок між концептуалізованими образами миру і війни: 3 незаконними збройними формуваннями спілкуватися можна лише за допомогою сили, поки вони не склали зброї [5, 2014, №69, с. 2]; За легалізацію зброї активно виступає Гриизенко, Ярош заявляє, щуо його бійціi $і$ не подумають здавати багнети... [5, 2014, №23, с. 2]; Ховати вам патрони ще зарано - Росія щуе лякає мари-кидком [5, 2014, №42, с. 4]; Петро Порошенко припинив перемир'я у зоні діï АТО [5, 2014, №53, с. 4].

Вербальними репрезентантами концепту «мир» подекуди виступають прецедентні тексти, як-от поетичні рядки із Шевченкового «Заповіту»: Ми перебуваємо на шляху до иілковитої перемоги $і$ з Божою допомогою невдовзі заживемо у «сім'i великій, сім'ї вольній, новій»... [5, 2014, №41, с. 5].

Окреслюючи номінативне поле концепту «мир», констатуємо, що воно охоплює чимало образних одиниць, серед яких паремії й афоризми (Крім приказки про такий-сякий мир, щцо кращий за війну, є ще одна: хочеш миру - готуйся до війни [5, 2014, №48, с. 2]); повтори, наприклад антонімічний (Найбільше тішить, шуо активнішими стали так звані мирні мешканці на немирних територіях [5, 2014, №46, с. 2]); метафоричні номінації (Але я певен, скоро на нашу землю прийде мир, злагода...[5, 2015, №64, с. 2]) та ін.

На те, що т. зв. воєнна метафора в українському газетно-публіцистичному мовленні зазнала кардинальних змін, ще в 2001 році звернула увагу О. Сербенська, зауважуючи: «Здобутки сучасної психо- та соціолінгвістики дають підставу зробити висновок: розгорнуте метафоричне поле, в якому явища політики, економіки та інших сфер перехрещуються $з$ реаліями війни, чинить тиск на суспільну свідомість $і$ призводить до їі мілітаризації, готує соціум до дій, що матеріалізують таку метафору» [1, с. 139].

Дослідження специфіки лінгвалізації концепту передбачає аналіз його семантико-аксіологічних особливостей. Як когнітивно багатогранний, концепт «мир»є полісемантичним.

Як уже згадувалося, в лінгвістичній традиції функціонує два слова мир. Перше охоплює чотири лексико-семантичні варіанти: 1. Відсутність незгоди, ворожнечі, сварок; згода (у 4 знач.). Жити в миру - жити мирно, дружно. 2. Відсутність збройної боротьби між двома або кількома народами, державами; протилежне війна. 3. Угода сторін, що воюють між собою, про припинення воєнних дій; мирний договір. 4. Спокій, Тиша. 3 миром відпускати, іти з миром, мир вам! Мир сьому дому! [2, с. 712]. Друге є більшою мірою застарілим і включає такі значення: 1. заст. Земля з усім, що на ній існує; світ. 2. Усе живе, усе, що оточує нас. 3. icm. Те саме, що громада. 4. засm. Життя мирян; світське життя, на протилежність монастирському [2, с. 712].

В українській етнолінгвокультурі поняття миру тлумачать як: 1) давню назву землі з усім, що на ній існує; світ; 2) усе живе, що оточує нас; тільки людей; 3) громаду і ширше - народ (перев. про селян); 4) життя мирян; світське життя на протилежність монастирському; 5) згоду, злагоду; відсутність збройної боротьби, війни [8, c. 363-364]. 
Аналіз досліджуваного матеріалу засвідчив, що, як і загальномовній практиці та етнокультурній традиції, ядерними в семантичній структурі концепту «мир» $\epsilon$ такі смисли: «той, що передбачає відсутність збройної боротьби, припинення вогню, вирішення конфлікту»: Президент пропонує припинення вогню як початок свого мирного плану врегулювання конфлікту. За його словами, вогонь буде припинений на обмежений термін для того, щоб дати можливість терористам та сепаратистам скласти зброю [5, 2014, №48, с. 4]; а отже, «потребує постійного захисту від ворогів, виборювання»: Спільне фото на згадку діти зробили спеиіально для наших воїнів, які захищають мир на Донбасі [5, 2015, №23, с. 4]; I хай їхня (волонтерів) копітка праия допоможе українським воїнам вибороти мир для України $[5,2018$, №54, с. 1]; «який асоціюється з тишею, спокоєм»: Головне питання, яке треба терміново вирімувати, забезпечити спокій в краӥні $[5,2014$, №50, с. 2]; Адже мир і спокій своєї Батьківщини для нього були понад усе [5, 2015, №20, с. 4]; За словами міністра, миротворча бригада буде виконувати завдання із забезпечення спокою громадян будьякої держави, в тому числі й України [5, 2014, №34, с. 4]; «символізує згоду, злагоду і ширше - любов та взаєморозуміння»: У хай у їхньому домі панують мир, злагода, любов та взаєморозуміння [5, 2014, №42, с. 5]; Але я певен, скоро на нашу землю прийде мир, злагода та ми разом подолаємо усі негаразди і труднощі [5, 2015, №64, с. 2].

Водночас у газетному тексті концепт «мир» помітно розширює свою семантику, насамперед через фрагмент концептуальної семантики із спільним компонентом «той, що асоціюється» та різними диференційними ознаками: «щастям»: Аби скоріш скінчилась ия війна, то иілий світ тоді б щасливий був! [5, 2015, №10, с. 10]; Щастя - ие Мир [5, 2015, №23, с. 4]); «здоров'ям»: Боротьба за мир-боротьба за здоров'я [5, 2015, №23, с. 1] (пор.: Бажаємо мічного козацького здоров'я, гармонї̈ у сім' та мирного неба над головою [5, 2014, №57, с. 12]); «єдністю, терпінням і взаємозумінням»: Чимало священнослужителів та політиків навіть у святкові дні говорили про ситуацію в Украйні, закликали до миру та єдності, терпіння та виваженості [5, 2014, №33, с. 5]; «волею»: Волю не дарують - тї здобувають [5, 2015, №41, с. 4]; «територіальною цілісністю»: Під час Хресної дороги за мир та цілісність Украйни $[5,2015$, №21, c. 1].

Нерідко автори публікацій осмислюють мир через поняття краси, сили і досконалості: Діти відтворили на папері Украӥну майбутнього, такою, якою вони хотіли б бачити ї̈ наяву -мирною, красивою, затишною, сильною та квітучою $[5,2017$, №26, с. 3] або ж через корелятивні зв’язки з вірою, надією, мрією, перемогою тощо: А чого варті дитячі малюнки - добрі, щирі, безпосередні, з вірою у перемогу та мир [5, 2017, №6, с. 6]; Діти Мар'їнки мріють про мир в Україні [5, 2017, №4, с. 6]; Разом ми прийдемо до спільної мети - великої перемоги Украйни [5, 2015, №18, с. 1]; Хай завжди будуть з нами перемога, весна, мир і спокій [5, 2016, №37, с. 2].

Як і поняття війни, мир - це «те, що усвідомлюється як сакральне» (за нього гинуть, жертвують найдорожчим - життям, моляться та просять у Бога і под.): Прийшли попрощатися з бійщем і багато людей, з якими він не був знайомий у житті, вони навколішки дякували йому за те, що він пожертвував життям за мирне небо над украӥнською землею [5, 2014, №18, с. 4]; Тернополяни провели неділю у молитві за мир і перемогу [5, 2017 №26, с. 1]; Нашими устами молитовно звучить благання про мир $[5,2015$, №21, с. 3]. 
Нерідко в одному контексті реалізується по декілька концептуальних смислів, як-от: Усі вони - Герої тих днів і нинішні Герої, усі поклали голови за мир $і$ спокій на нашій землі, за щасливе майбутнє своїх нащадків [5, 2014, №48, с. 2] («той, що асоціюється зі спокоєм, щасливим життям», «за який борються і гинуть», а отже, «який $\epsilon$ найвищою цінністю»)

Чимало смислів тлумачимо як авторські, зокрема такі, як «той, що символізує живий знак»: Присутні вишикувалися, символічно сформувавши слово МИР [5, 2017, №26, с. 3] або «який підвладний магічній силі»: I, яким би скептиком не був, дуже хочеться вірити, що гвинтівка, яка впала у гвардійця з президентської варти перед інавгурацією, таки стане провісником відновлення миру в країні $[5,2014$, №46, с. 2].

Когнітивну багатогранність досліджуваного концепту засвідчує й об'єктивація інших концептуальних ознак, пов'язаних із поняттям миру, на зразок: «міждержавний», «економічний», «політичний», «родинний», «душевний» (Мир буває різним: міждержсавним, всередині краӥни, економічним, політичним, родинним, дущевнимм $[5,2015$, №75, с. 1]).

Проаналізовані контексти засвідчили, що концепт «мир» характеризується яскраво вираженим оцінним забарвленням: Молоді хлопиі і дівчата зізнавалися, щңо їм хочеться хоч якось віддячити солдатам, які оберігають наш мир $i$ захищають Україну... [5, 2014, №46, с. 6]. На відміну від концептуалізованого поняття війни, що конотує розпач і біль, концепт «мир» об'єктивується насамперед як позитивно маркований, що реалізує уявлення про найбільшу цінність - життя: Переконані, щчо перемога буде, але хочеться, щоб не такою дорогою ціною платила Украйна за мир і спокій [5, 2014, №63, с. 1]; Адже там за наш з вами спокій, мир умирають хлопці, сиротіють діти, матері хоронять синів [5, 2014, №16, с. 4]; рідше - набуває негативного забарвлення, частіше іронічного: Бо хіпарі щиро вважали, же тільки Раша є опертям миру на Землі $[5,2014$, №59, с. 9].

Отже, концепт «мир» є когнітивно багатоплановим позитивно маркованим лінгвоментальним феноменом, широко представленим у мас-медійному дискурсі. Аналіз показав, що він часто об’єктивується в газетних текстах періоду війни (2014 - 2019 рр.), де характеризується розгалуженим номінативним полем. Серед засобів його вербалізації одиниці різних мовних рівнів: лексичного, фразеологічного, словотвірного, граматичного. Виявлено також тропеїчні конструкції на позначення вказаного концептуалізованого поняття. Усі розглянуті назви забезпечують емоційність, образність газетних публікацій і є оцінно забарвленими. Специфіку лінгвалізації концепту значною мірою визначає його семантика й аксіологічні характеристики, які, з одного боку, засвідчують його загальномовні та етнокультурні особливості, а з іншого - індивідуально-авторські.

Перспективним вважаємо грунтовне дослідження концепту «мир» в аспекті реалізації ним опозитивних відношень «війна - мир» в українському етнокультурному просторі (на матеріалі інших текстів, в тому числі й мас-медійних). 


\section{REFERENCES}

1. Волощак М.Й., Сербенська О.А. Актуальне інтерв’ю з мовознавцем: 140 запитань і відповідей. К.: Просвіта, 2001. 204 с.

2. Словник української мови: в 11 т. / За заг. ред. І. К. Білодіда. К. : Наукова думка, 1973. T. 4. $840 \mathrm{c}$.

3. Дейк ван Т. А. Язык. Познание. Коммуникация / Пер. с англ.; сост. В. В. Петрова; под. ред. В. И. Герасимова; вступ, ст. Ю. Н. Караулова и В. В. Петрова. М. : Прогресс, 1989. 312 с.

4. Попова 3. Д., Стернин И. А. Когнитивная лингвистика. М.: АСТ: Восток - Запад, 2010. 314 c.

5. Свобода. 2014-2018.

6. Огієнко І. Етимологічно-семантичний словник української мови: у 4 т. Вінніпег: Волинь, 1979-1995. Т. 3. 415 с.

7. Словник синонімів української мови: в 2 т. / А.А.Бурячок, Г. М.Гнатюк, С. І. Головащук та ін. К. : Наукова думка, 1999. Т. 1. 1030 с.

8. Жайворонок В. В. Знаки української етнокультури : словник-довідник. К.: Довіра, 2006. 703 c. 


\title{
SPECIFICATION OF LINGUALIZATION OF CONCEPT «PEACE» IN MASS MEDIA TEXT
}

\author{
Tetiana Vilchynska \\ Ternopil national pedagogical university \\ 2 Maxyma Kryvonosa str., 46027, Ternopil, Ukraine \\ e-mail: tetyanav@ukr.net \\ https://orcid.org/0000-0003-4881-6132
}

Studies of the peculiarities of lingual conceptualization of the cultural space through concepts have been one of the priority directions in the modern linguistics for a long time. Despite the fact that a plenty of conceptual units had been an object of thorough research, verbalization peculiarities of concept «PEACE» in Ukrainian linguoculture was primarily beyond the scope of previous works. Only some of its certain have been analyzed by Lyudmila Venediktova, Ulyana Ivanova-Karpenko, Olexanrd Kolesnyk, Halyna Yavorska etc. Furthermore, the investigation of concept «PEACE» based on mass-media material remains a topical challenge. This research aims to point out specifics of the concept «PEACE» verbalization in Ukrainian newspaper text, particularly in Svoboda - the newspaper of the Ternopil region - during 2014 -2019 when the articles about war were constantly present on its pages.

The conducted analysis demonstrates that the concept «PEACE» obtains an extensive nominative field on the Svoboda pages. The means of its verbalization consist of lexical, phraseological and grammar units. Here belongs the main name of the concept and its synonyms (including borrowed ones), attributive and predicative syntagmas, phraseological units. We found the glaring amount of figurative devises, especially metaphors and metaphorical epithets. Due to the fact that the majority of the concept lingual representations are stylistically marked with evaluation, media texts have a high level of emotionality and expressivity.

There is a tendency for the authors of the newspaper texts about the war not only to use nominative means which are traditional for Ukrainian linguoculture but also to employ their own frequently figurative constructions. Lingual instantiation of the investigated concepts revealed journalists' positive and negative attitudes to war and peace, enemies and defenders etc. These issues can become a subject of further research. We consider the rigorous investigation into the concepts «WAR» and «PEACE» in the aspect of realization of their oppositional relations in Ukrainian ethnocultural space based on different texts' material particularly promising.

Key words: concept, peace, verbalization, nominative field, newspaper text. 